\title{
PENGARUH PENDEKATAN MODEL-ELICITING ACTIVITIES TERHADAP KEMAMPUAN KOMUNIKASI MATEMATIK SISWA SMP
}

\author{
M. Afrilianto \\ muhammadafrilianto1@gmail.com
}

Program Studi Pendidikan Matematika, STKIP Siliwangi

\begin{abstract}
ABSTRAK
Penelitian ini bertujuan untuk menelaah pencapaian kemampuan komunikasi matematik siswa yang menggunakan pendekatan Model-Eliciting Activities dibandingkan dengan yang menggunakan pembelajaran biasa. Metode yang digunakan dalam penelitian ini yaitu metode eksperimen, dengan desain kelompok kontrol pretes-postes. Populasi pada penelitian ini adalah seluruh siswa SMP di Kota Bandung, sedangkan sampel penelitiannya adalah sebanyak dua kelas dari kelas VII yang dipilih secara acak dari seluruh kelas VII yang ada. Kemudian kedua kelas tersebut dipilih menjadi kelas eksperimen dan kelas kontrol. Kelas eksperimen memperoleh pendekatan Model-Eliciting Activities dan kelas kontrol memperoleh pembelajaran biasa. Instrumen yang digunakan dalam penelitian ini berupa soal tes kemampuan komunikasi matematik. Data hasil penelitian dianalisis secara kuantitatif dengan menggunakan uji statistik (uji-t). Kesimpulan yang diperoleh yaitu kemampuan komunikasi matematik siswa yang memperoleh pembelajaran dengan pendekatan Model-Eliciting Activities lebih baik daripada yang memperoleh pembelajaran biasa.
\end{abstract}

Kata Kunci: Komunikasi Matematik, Pendekatan Model-Eliciting Activities

\begin{abstract}
This study aims to examine the achievements students' mathematical communication ability between those who acquire learning through with Model-Eliciting Activities learning approach and conventional learning. The method was used in this study is the experimental method, with pretest-posttest control group design. The population was the entire students of SMP in Bandung, while the sample is two classes of grade VII selected randomly from all the existing class of grade VII. Then these two classes were randomly assigned into experimental class and control class. Experimental class with Model-Eliciting Activities learning approach and control class gets conventional learning. Research instruments include tests of mathematical communication ability. The data were analyzed using t-test and the Mann-Whitney test. The results showed that Students' achievement of mathematical communication ability of mathematical learning through with Model-Eliciting Activities learning approach is better than through conventional learning.
\end{abstract}

Keywords: Mathematical Communication, Model-Eliciting Activities Learning Approach

\section{A. PENDAHULUAN}

Matematika merupakan ilmu universal yang mendasari perkembangan teknologi modern dan berbagai disiplin ilmu serta mampu mengembangkan daya pikir manusia. Oleh karena itu, matematika perlu diajarkan di setiap jenjang pendidikan sebagai bekal pengembangan kemampuan menggunakan bahasa matematika dalam mengkomunikasikan ide atau gagasan matematika untuk memperjelas suatu situasi.

Menurut Reys, dkk (Suherman, et.al., 2003:17), “ 'Matematika adalah telaah tentang pola dan hubungan, suatu jalan atau pola berpikir, suatu seni, suatu bahasa, dan suatu alat' ". Dari salah satu pengertian matematika sebagai suatu bahasa maka perlu kiranya siswa memiliki kemampuan untuk mengkomunikasikan ide matematik mereka. Kemampuan komunikasi matematik bukan hanya sebagai suatu kompetensi siswa yang harus diajarkan dan dipelajari, tetapi hendaknya diupayakan agar siswa mampu memecahkan suatu permasalahan matematika.

Salah satu tujuan yang ingin dicapai dalam keberhasilan pembelajaran matematika adalah kemampuan komunikasi matematik. Hal ini sejalan 
dengan pendapat Huinker dan Laughlin (Hulukati, 2005:5) menyebutkan, “ '...salah satu tujuan yang ingin dicapai dalam pembelajaran matematika adalah memberikan kesempatan seluas-luasnya kepada para siswa untuk mengembangkan dan mengintegrasikan keterampilan berkomunikasi melalui lisan maupun tulisan serta mempresentasikan apa yang telah dipelajari' ’.

Faktor penyebab ketidakberhasilan belajar yang berimbas pada lemahnya kemampuan komunikasi matematik siswa mungkin saja dari ketidaktepatan penyajian ataupun metode pengajarannya. Seperti yang diungkapkan Ruseffendi (2006:465), “...yang mungkin menjadi penyebab kesukaran anak belajar ialah...mungkin karena kesalahan: gurunya, penyajiannya, metodenya, alat peraga/permainannya". Terkadang dalam pembelajaran terselip kegiatan atau soal yang sebenarnya belum waktunya untuk diberikan. Apalagi dengan matematika yang dihadapkan dengan cara berhitung dan konsep-konsep yang abstrak, maka perlu adanya perhatian khusus dalam pengajarannya

Kegiatan pembelajaran sebagian besar masih kurang inovasi. Selettenhaar (Permana, 2010:5) mengatakan, " 'Pada model pembelajaran sekarang ini, umumnya aktifitas siswa hanya mendengar dan menonton pelajaran guru, kemudian guru menyelesaikan soal sendiri dengan satu cara penyelesaian dan memberi soal latihan untuk diselesaikan sendiri oleh siswanya".

Seorang ahli bernama Piaget mengelompokkan siswa yang berumur sekitar 11 tahun sudah mulai masuk ke dalam tahap operasi formal (Ruseffendi, 2006:134). Salah satu ciri tahapan ini, yaitu siswa memasuki peralihan antara berfikir konkrit menuju berfikir abstrak. Seyogianya, seorang guru jenjang SMP awal tidak serta merta memberikan pengajaran matematika dengan cara seperti memberikan pengajaran kepada siswa yang sudah terbiasa berpikir operasi formal. Perlu adanya pendekatan pembelajaran yang mampu mengarahkan siswa untuk menyederhanakan konteks permasalahan matematik ke dalam ide, ekspresi maupun model matematik sesuai tingkat pemahamannya.

Pada penelitian ini, peneliti mengajukan pendekatan pembelajaran yang membantu mengarahkan siswa dalam menyelesaikan konteks permasalahan matematik melalui proses pemodelan. Masalah yang ditimbulkan dalam pendekatan ini dirancang untuk menantang siswa untuk membangun model dan memecahkan masalah dalam konteks kehidupan siswa.

Pendekatan Model-Eliciting Activities menuntun siswa untuk dapat mengurai elemen-elemen, memahami hubungan konsep antar elemen, serta mengidentifikasi aturan yang berlaku untuk hubungan dan operasi. Dengan cara ini, siswa diarahkan untuk membuka proses berfikir mereka dalam mencari dan mengembangkan solusi terhadap permasalahan yang disajikan.

Berdasarkan latar belakang masalah yang telah diuraikan sebelumnya, maka rumusan masalah dalam penelitian ini diuraikan yaitu apakah kemampuan komunikasi matematik siswa SMP yang pembelajarannya pendekatan Model-Eliciting Activities lebih baik daripada yang menggunakan pembelajaran biasa?

Penelitian ini diharapkan bermanfaat, salah satunya yaitu dapat memberikan gambaran dan informasi mengenai pendekatan Model-Eliciting Activities, sehingga dapat dijadikan bahan rujukan dan mengembangkannya dalam pembelajaran matematika.

\section{B. KAJIAN TEORI DAN METODE}

\section{Kajian Teori}

\section{a. Kemampuan Komunikasi Matematik}

Komunikasi merupakan bagian yang tidak dapat dipisahkan dalam suatu pembelajaran, termasuk dalam pembelajaran matematika. Komunikasi matematik telah tercantum pada salah satu tujuan pembelajaran matematika sekolah menengah dalam Kurikulum Tingkat Satuan Pendidikan yaitu, “...mengkomunikasikan gagasan dengan simbol, tabel, diagram, atau media lain untuk memperjelas keadaan atau masalah..." Depdiknas (2006:36).

Dalam tujuan tersebut, ada beberapa unsur penting terkait kemampuan komunikasi matematik, diantaranya: gagasan, simbol, tabel, diagram atau media. Namun, terdapat perbedaan karakteristik antara unsur-unsur tersebut dalam matematika dengan yang terdapat dalam bahasa lain. Perbedaan tersebut menjadikan matematika sebagai bahasa yang bersifat unik dengan memiliki keunggulan tertentu. Sumarmo (2012:2) mengatakan, 
Keunggulan dari simbol, gambar, atau pola matematika dari lainnya adalah terletak pada sifatnya yang tetap yang memiliki idea tertentu. Simbol, gambar dan pola tersebut bukan merupakan gambar material baik konkrit atau abstrak dari benda yang bersangkutan, melainkan menyatakan perumpamaan dari elemen, operasi, relasi, dan atau fungsi dalam kerangka ruang dan waktu.

Selain tercantum dalam kurikulum, pentingnya kepemilikan kemampuan komunikasi matematik juga menjadi jembatan para siswa untuk mengolah pemahaman mereka untuk dapat memecahkan masalah matematik. Peran penting kemampuan komunikasi juga dikemukakan oleh Asikin yaitu, “ '...membantu siswa membangun pengetahuan matematiknya, meningkatkan kemampuan pemecahan masalah matematik..." " (Sumarmo, 2012:14).

Kemampuan komunikasi juga tidak terlepas dari salah satu pengertian matematika itu sendiri yaitu sebagai bahasa simbolik yang memungkinkan terjadinya transfer informasi yang padat makna, tidak mendua arti dan bersifat universal. Sumarmo (2014:428) merangkum pendapat beberapa pakar dan NCTM dan mengidentifikasi beberapa kemampuan komunikasi matematik antara lain: a) Menyatakan suatu situasi ke dalam bentuk gambar, diagram, bahasa, simbol, ekspresi atau model matematik; b) Menyatakan gambar, bahasa, simbol, ekspresi atau model matematik ke dalam bahasa sendiri; c) Mendengarkan, berdiskusi, menulis matematika; Membaca suatu presentasi matematik disertai pemahaman; e) Mengungkapkan kembali suatu uraian matematik dalam bahasanya sendiri; dan f) Menyusun pertanyaan tentang matematika.

NCTM (Elida, 2012:180) menyatakan bahwa kemampuan komunikasi siswa dalam pembelajaran matematika dapat dilihat dari,

1) Kemampuan mengekspresikan ide-ide matematika melalui lisan, tertulis, dan mendemonstrasikannya serta menggambarkannya secara visual.

2) Kemampuan memahami, menginterpretasikan dan mengevaluasi ide-ide matematika baik secara lisan, tulisan, maupun bentuk visual lainnya.

3) Kemampuan dalam menggunakan istilahistilah, notasi-notasi matematika dan strukturstrukturnya, untuk menyajikan ide-ide, menggambarkan hubungan-hubungan dan model-model situasi.

Menurut Sumarmo (2012:14) komunikasi matematik meliputi kemampuan siswa,

a) Menghubungkan benda nyata, gambar, dan diagram ke dalam ide matematika

b) Menjelaskan ide, situasi dan relasi matematik secara lisan dan tulisan dengan benda nyata, gambar, grafik dan aljabar

c) Menyatakan peristiwa sehari-hari dalam bahasa atau simbol matematika

d) Mendengarkan, berdiskusi dan menulis tentang matematika

e) Membaca dengan pemahaman suatu presentasi matematika tertulis

f) Membuat konjektur, menyusun argumen, merumuskan definisi dan generalisasi

g) Mengungkapkan kembali suatu uraian atau paragraf matematika dalam bahasa sendiri.

Selain itu, indikator kemampuan komunikasi tertulis dikemukakan oleh Cai, Lane, dan Jakabsin (Fitriah, 2011:23) terbagi ke dalam tiga kategori,

(1) Menulis (Written Text) yaitu memberikan jawaban dengan menggunakan bahasa sendiri dan menyusun suatu argumen

(2) Menggambar (Drawing) yaitu mempresentasikan benda-benda nyata, gambar, dan diagram kedalam ide-ide matematik, begitu pula sebaliknya.

(3) Ekspresi Matematik (Mathematical Expression) yaitu mengekspresikan konsep matematika dengan menyatakan peristiwa sehari-hari dalam bahasa atau simbol matematis, misalnya model matematis atau persamaan aljabar.

\section{b. Pendekatan Model-Eliciting Activities}

"Pendekatan Model-Eliciting Activities adalah pendekatan pembelajaran untuk memahami, menjelaskan dan mengkomunikasikan konsepkonsep yang terkandung dalam suatu sajian melalui proses pemodelan matematika" (Permana, 2010:34). Model-Eliciting Activities terbentuk pada permulaan tahun 1970 oleh seorang professor dan pendidik matematika yaitu Lesh.

Lesh mengharapkan guru menggunakan pendekatan ini agar siswa dapat membentuk sebuah model matematik berupa sistem konseptual yang membuat siswa merasakan beragam pengalaman matematik tertentu. Jadi siswa tidak hanya bisa menghasilkan model matematik tetapi 
juga diharapkan mengerti konsep-konsep yang digunakan dalam pembentukan model matematik dari permasalahan yang diberikan.

Secara lebih khusus, Chamberlin (Hanifah, 2013:14) menguraikan langkah-langkah pelaksanaan MEAs,

1) Pendidik membaca lembar permasalahan yang mengembangkan konteks peserta didik

2) Peserta didik siap siaga terhadap pertanyaan berdasarkan lembar permasalahan tersebut

3) Pendidik membacakan permasalahan bersama peserta didik dan memastikan bahwa setiap kelompok mengerti apa yang sedang ditanyakan

4) Peserta didik berusaha untuk menyelesaikan masalah tersebut

5) Peserta didik mempresentasikan model matematik mereka setelah membahas dan meninjau ulang solusi.

Dalam penelitian ini, pembelajaran menggunakan pendekatan Model-Eliciting Activities menerapkan langkah-langkah:

a) Siswa diberi sebuah masalah yang konteks dengan kehidupan siswa

b) Siswa secara bertahap menanggapi serangkaian pertanyaan yang berkaitan dengan konteks masalah dan mulai terlibat dengan situasi masalah yang diberikan

c) Siswa bekerja secara berkelompok untuk menyelesaikan masalah tersebut

d) Setiap kelompok menuliskan solusi masalah dan memberikan hasil jawaban mereka kepada guru

e) Setiap kelompok dengan jawaban yang berbeda mempresentasikan solusi mereka di depan kelas

f) Guru bersama siswa membahas solusi yang berbeda dan efektivitas dari masing-masing solusi tersebut untuk menyelesaikan permasalahan.

\section{Metode}

Metode yang digunakan dalam penelitian ini adalah metode eksperimen, dengan desain kelompok kontrol pretes-postes. Pada jenis desain eksperimen ini terjadi pengelompokan subjek secara acak kelas, adanya pretes dan postes. Kelas eksperimen yaitu kelas yang mendapatkan pembelajaran dengan pendekatan Model-Eliciting Activities. Kelas kontrol yaitu kelas yang mendapatkan pembelajaran biasa. Desain penelitiannya (Ruseffendi, 2010:50) berbentuk:

$\begin{array}{llll}\text { A } & \text { O } & \mathrm{X} & \mathrm{O} \\ \mathrm{A} & \mathrm{O} & & \mathrm{O}\end{array}$

Keterangan:

A : Sampel penelitian dipilih secara acak kelas

$\mathrm{O} \quad:$ Pretes $=$ Postes

X : Pembelajaran dengan Pendekatan ModelEliciting Activities

Populasi pada penelitian ini adalah seluruh siswa di salah satu SMP di Kota Bandung. Sampel yang diambil dalam penelitian ini adalah siswa kelas VII. Dari beberapa kelas VII, kemudian dipilih secara acak kelas dua kelas sebagai kelas eksperimen dan kelas kontrol. Instrumen yang digunakan adalah instrumen tes berbentuk uraian untuk mengukur kemampuan komunikasi matematik siswa.

\section{HASIL DAN PEMBAHASAN}

\section{Hasil Penelitian}

Pada bagian ini disajikan data hasil penelitian serta analisis menggunakan uji statistik. Data deskriptif hasil penelitian sebelum dan sesudah pembelajaran disajikan dalam tabel rekapitulasi berikut ini.

Tabel 1. Rekapitulasi Hasil Pretes dan Postes Kemampuan Komunikasi Matematik

\begin{tabular}{|c|c|c|c|}
\hline \multirow[b]{2}{*}{ Kelas } & \multirow[b]{2}{*}{ Tes } & \multirow[b]{2}{*}{ Stat. } & Aspek Kemampuan \\
\hline & & & $\begin{array}{l}\text { Komunikasi } \\
\text { Matematik }\end{array}$ \\
\hline \multirow{4}{*}{$\begin{array}{l}\text { Eksperimen } \\
\text { (PMEA) }\end{array}$} & \multirow[b]{2}{*}{ Pretes } & $\overline{\mathrm{x}}$ & 8,48 \\
\hline & & $\mathrm{s}$ & 2,32 \\
\hline & \multirow{2}{*}{ Postes } & $\overline{\mathrm{x}}$ & 18,38 \\
\hline & & $\mathrm{s}$ & 2,71 \\
\hline \multirow{4}{*}{$\begin{array}{l}\text { Kontrol } \\
\text { (PB) }\end{array}$} & \multirow{3}{*}{ Pretes } & $\overline{\mathrm{x}}$ & 9,27 \\
\hline & & $S$ & 2,47 \\
\hline & & $\overline{\mathrm{x}}$ & 14,30 \\
\hline & Postes & $\mathrm{s}$ & 2,40 \\
\hline
\end{tabular}

Berdasarkan tabel di atas, rata-rata kemampuan awal (pretes) komunikasi matematik PMEA dibandingkan dengan PB tidak jauh berbeda. Setelah pembelajaran dilaksanakan, hasil postes kemampuan komunikasi matematik antara PMEA dengan PB, memperlihatkan perbedaan. Rata-rata hasil postes kemampuan komunikasi matematik PMEA lebih tinggi daripada PB. 
Berdasarkan uraian di atas, rata-rata kemampuan komunikasi matematik PMEA lebih tinggi daripada PB, dilihat dari pencapaian hasil belajar (postes). Hal tersebut akan dianalisis menggunakan uji statistik dengan menguji perbedaan rata-rata kedua kelas.

\section{a. Analisis Data Pretes Kemampuan Komunikasi Matematik}

Analisis data pretes dilakukan dengan penghitungan uji perbedaan rata-rata data pretes kemampuan komunikasi matematik siswa antara yang menggunakan PMEA dan PB menggunakan uji-t. Hasilnya disajikan pada Tabel 2.

\section{Tabel 2. Hasil Uji Perbedaan Rata-Rata Data} Pretes Kemampuan Komunikasi Matematik

\begin{tabular}{ccc}
\hline $\begin{array}{c}\text { Aspek } \\
\text { Kemampuan }\end{array}$ & $P$-Value & $\mathrm{H}_{0}$ \\
\hline $\begin{array}{l}\text { Komunikasi } \\
\text { Matematik }\end{array}$ & 0,149 & Terima \\
\hline
\end{tabular}

Hipotesis yang diuji untuk kemampuan awal komunikasi matematik yaitu:

$\mathrm{H}_{0}$ : Tidak terdapat perbedaan kemampuan awal komunikasi matematik siswa yang memperoleh pendekatan Model- Eliciting Activities dan pembelajaran biasa.

$\mathrm{H}_{1}$ : Terdapat perbedaan kemampuan awal komunikasi matematik siswa yang memperoleh pendekatan Model- Eliciting Activities dan pembelajaran biasa.

Dari Tabel 2, dapat dilihat bahwa hipotesis nol diterima. Artinya tidak terdapat perbedaan kemampuan awal komunikasi matematik kelas PMEA dengan PB.

\section{b. Analisis Data Postes Kemampuan Komunikasi Matematik}

Analisis data postes dilakukan dengan penghitungan uji perbedaan dua rata-rata data postes kemampuan komunikasi kelas PMEA dan PB menggunakan uji-t.
Tabel 3. Hasil Uji Perbedaan Rata-Rata Postes Kemampuan Komunikasi Matematik

\begin{tabular}{lcc}
$\begin{array}{c}\text { Aspek } \\
\text { Kemampuan }\end{array}$ & $P$-Value & $\mathrm{H}_{0}$ \\
\hline $\begin{array}{l}\text { Komunikasi } \\
\text { Matematik }\end{array}$ & 0,000 & Tolak \\
\hline
\end{tabular}

Hipotesis yang diuji untuk kemampuan komunikasi matematik yaitu:

$\mathrm{H}_{0}$ : kemampuan komunikasi matematik siswa kelas PMEA tidak lebih baik atau sama dengan PB.

$\mathrm{H}_{1}$ : kemampuan komunikasi matematik Siswa kelas PMEA lebih baik daripada PB.

Berdasarkan Tabel 3, hipotesis nol ditolak, sehingga hipotesis kedua atau hipotesis alternatif $\left(\mathrm{H}_{1}\right)$ diterima. Dengan demikian dapat disimpulkan bahwa kemampuan komunikasi matematik siswa yang memperoleh pembelajaran dengan pendekatan Model-Eliciting Activities lebih baik daripada yang memperoleh pembelajaran biasa.

\section{Pembahasan}

Berdasarkan hasil analisis data yang dikemukakan pada bagian sebelumnya, rata-rata postes kelas eksperimen dan kelas kontrol berturut-turut adalah 18,38 dan 14,30 dengan Skor maksimum 28. Ini berarti pencapaian kemampuan komunikasi matematik setelah diberi perlakuan pada kelas eksperimen $65,7 \%$ dan kelas kontrol 51,1\%. Terlihat bahwa perbedaan rerata postes cukup besar, kemampuan komunikasi matematik kelas eksperimen lebih baik secara signifikan daripada kelas kontrol.

Berikut variasi jawaban siswa pada setiap soal,

a. Siswa telah banyak yang bisa menggambar segitiga berdasarkan ukuran sudut tertentu;

b. Banyak siswa dapat membuat model matematik untuk menghitung keliling taman berbentuk segitiga dan menguhubungkan konsep perhitungan dengan peristiwa seharihari;

c. Argumen siswa dalam jawaban cukup sistematis;

d. Siswa sudah nampak mahir dalam pemanipulasian aljabar untuk mendapatkan rumus luas daerah belah ketupat, hal ini menunjukkan pemahaman aljabar mereka meningkat;

e. Banyak siswa sudah bisa menghitung luas kamar dan luas keramik, dan beberapa sudah 
bisa memberikan jawaban yang tepat dengan argumen yang lengkap;

f. Beberapa siswa mampu mempresentasikan informasi yang ada pada soal ke dalam konsep gambar geometri (bangun segiempat yang sederhana);

g. Siswa sudah relatif mahir mengekspresikan konsep luas ketika dikaitkan dengan per satuan luas serta menghubungkannya ke dalam pertanyaan poin (c) pada soal postes.

\section{KESIMPULAN}

Dari hasil penelitian ini diperoleh kesimpulan yaitu pencapaian kemampuan komunikasi matematik siswa yang memperoleh pembelajaran dengan pendekatan Model-Eliciting Activities lebih baik daripada yang memperoleh pembelajaran biasa.

Berdasarkan kesimpulan di atas, maka peneliti mengemukakan beberapa saran sebagai berikut:

1. Bagi guru matematika, pembelajaran dengan pendekatan Model-Eliciting Activities sebaiknya digunakan sebagai salah satu alternatif pendekatan pembelajaran di kelas, terutama untuk meningkatkan kemampuan komunikasi matematik siswa.

2. Pembelajaran matematika dengan pendekatan Model-Eliciting Activities sebaiknya dapat diterapkan dalam jangka waktu yang lebih lama, dengan tujuan agar proses pembelajaran menjadi lebih optimal.

3. Untuk menerapkan pembelajaran dengan pendekatan Model-Eliciting Activities, sebaiknya guru membuat sebuah perencanaan yang lebih baik, sehingga pembelajaran dapat berjalan secara sistematis sesuai dengan rencana.

4. Perlu dilakukan penelitian lanjutan pada jenjang pendidikan lainnya seperti SD/MI, MTs, SMA, SMK, MA, dan perguruan tinggi.

\section{E. DAFTAR PUSTAKA}

Depdiknas. (2006). Pedoman Penyusunan Kurikulum Tingkat Satuan Pendidikan Sekolah Dasar. Jakarta: Depdiknas.

Elida, N. (2012). Meningkatkan Kemampuan Komunikasi Matematik Siswa Sekolah Menengah Pertama melalui Pembelajaran Think-Talk-Write (TTW). Infinity Journal, 1, 126-196.

Fitriah, P. (2011). Penerapan Model Pembelajaran Siklus Belajar 7E untuk Meningkatkan Kemampuan Komunikasi Matematis Siswa
SMP. FMIPA UPI. Bandung: Tidak diterbitkan.

Hanifah, T. (2013). Peningkatan Kemampuan Berfikir Kritis Siswa SMP melalui Pendekatan Model-Eliciting Actifities (MEAs) dalam Pembelajaran Matematika. FMIPA UPI. Bandung: Tidak diterbitkan.

Hulukati, E. (2005). Pengembangan Kemampuan Komunikasi dan Pemecahan Masalah Matematika Siswa SMP melalui Model Pembelajaran Generatif. Disertasi SPs UPI. Bandung: Tidak diterbitkan.

Permana, Y. (2010). Mengembangkan Kemampuan Pemahaman, Komunikasi dan Disposisi Matematis Siswa SMA melalui ModelEliciting Activities. Disertasi SPs UPI. Bandung: Tidak diterbitkan.

Ruseffendi, E. T. (2006). Pengantar kepada Membantu Guru Mengembangkan Kompetensinya dalam Pengajaran Matematika untuk Meningkatkan CBSA. Bandung: Tarsito.

Ruseffendi, E. T. (2010). Dasar-Dasar Penelitian Pendidikan dan Bidang Non-Eksakta Lainnya. Bandung: Tarsito.

Suherman, et.al. (2003). Strategi Pembelajaran Matematika Kontemporer. Bandung: JICA UPI.

Sumarmo, U. (2012). Bahan Ajar Mata Kuliah Proses Berpikir Matematik Program S2 Pendidikan Matematika STKIP Siliwangi Bandung. Cimahi: Tidak diterbitkan.

Sumarmo, U. (2014). Kumpulan Makalah Berpikir dan Disposisi Matematik serta Pembelajarannya. Jurusan Pendidikan Matematika FPMIPA UPI. Bandung: Tidak diterbitkan. 